\title{
INFLATION AND MONETARY POLICY IN AUGUST 2015
}

\author{
A.Bozhechkova
}

The Russian currency in July-August saw further substantial depreciation in the exchange rate. The weakening of the ruble resulted largely in higher inflation and retained the central bank base rate at the level which was set in September at a meeting of the Central Bank Board of Directors. The Consumer Price Index (CPI) in August kept increasing up to $0.4 \%$ (0.2\% in August 2014), reaching the August-end highest value for the first time since 2010, when the CPI gained $0.6 \%$. Price growth rates accelerated most during the last week of August, when the CPI gained $0.2 \%$. In the first three weeks of September consumer prices saw another hike of $0.5 \%$.

While inflation in July was boosted mostly due to indexation of utility service tariffs, prices in August and September increased chiefly because of drastic depreciation of the ruble which was similar to that earlier in the year following the fall of crude oil prices. The growth rate of the Consumer Price Index (CPI) in August 2015 gained $15.8 \%$ compared to the same period of 2014, up 0.2 p.p. from July (Fig. 1).

The Core Consumer Price Index in August stood at $100.8 \%$, much higher than the CPI. This was most of all determined by a seasonal component which pushed down prices of food products in summer season, and the core CPI is calculated without using this component. Additionally, the situation is explained by the fact that the value of the consumer baskets covered by the $\mathrm{CPI}$ and the core CPI shows different sensitivity to the devaluation of the national currency. Depreciation of the ruble traditionally tends to have a much stronger effect on increase of prices of marketable goods which are basically used for calculating the core CPI compared to that of nonmarketable goods which comprise a substantial share of the basket for calculating the CPI.

The food product sector saw further deflation in August: prices of food products saw an average decline of $0.7 \%(-0.3 \%$ in July). Fruits and vegetables were leading in terms of seasonal price fall, with prices showing a negative growth rate of $9.8 \%$ (-4.2\% in July). In August, prices in the group of non-food products increased $0.8 \%$ ( $0.5 \%$ in July). The depreciation of the ruble which began as early as in May and reached its peak in August 2015 resulted in a substantial increase in prices of electric products and other home appliances (from $0.2 \%$ in July to $1.0 \%$ in August), clothes (from $0.3 \%$ to $0.8 \%$ ), footwear (from $0.2 \%$ to $0.9 \%$ ), knitwear (from $0.4 \%$ to $0.8 \%$ ), and medicaments (from $0.3 \%$ in July to $0.5 \%$ in August).

Prices and tariffs of paid services to individuals in August increased $1.3 \%$. Prices of outbound tour- ism services increased $9.8 \%$ ( $4.6 \%$ in July) due to the exchange rate dynamics and seasonal factor (Fig. 2).

It was noted in the Bank of Russia's monetary policy report for September that the respondents expect the next year inflation to increase from 12.8-13.9\% in July to $13.7-14.8 \%$ in August, according to surveys conducted in August by OOO INFORM (a limited liability company). It is our opinion that amid large scale depreciation of the national currency in the recent few months, the 2015 year-end inflation is most probably anticipated to reach a value higher than $13 \%$.

The Consumer Price Index (CPI) in the first three weeks of September gained $0.5 \%$ (a total of $0.7 \%$ in September 2014). Monetary factors still have a downward pressure on inflation. The monetary base increased 3.1\% compared to that in August 2014. Growth rates of the monetary base were relatively slow mostly due to a decrease in volumes of liquidity provided by the Bank of Russia to commercial banks, this is because of stabilized situation in the money market and slightly weaker demand by commercial banks for central bank's ruble-denominated resources.

The monetary base (broad definition) in August 2015 remained almost unchanged, running at $\mathrm{Rb}$ $9837.2 \mathrm{bn}$ as of the beginning of September. The fol-

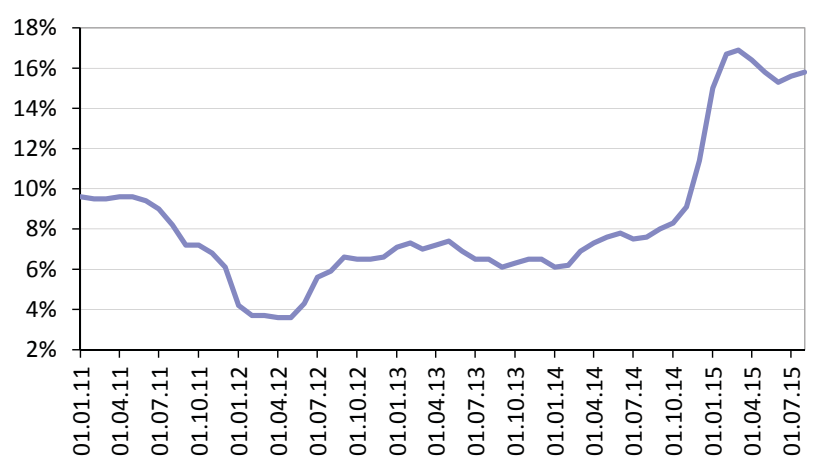

Source: The Federal State Statistic Service of Russia (Rosstat). Fig. 1. CPI growth rate in 2011 to 2015 (YOY percentage change) 
lowing components of the broad monetary base increased in August: the required reserves (a growth of $2.5 \%$ to $\mathrm{Rb} 489.1 \mathrm{bn}$ ); the volume of cash in circulation including cash balances in credit institutions increased $0.5 \%$ to $\mathrm{Rb} 7760.0 \mathrm{bn}$; banks' balances on correspondent accounts held with the Bank of Russia increased $0.7 \%$ to $\mathrm{Rb} 1297.1 \mathrm{bn}$. Banks' deposits shrank by $9.5 \%$ to $\mathrm{Rb} 291.1 \mathrm{bn}$. The narrow monetary base (cash plus required reserves) in August increased 0.6\% to Rb 8060.5bn (Fig. 3).

The average daily volume of reserves in commercial banks in August was 2.6\% higher than that in July, reaching $\mathrm{Rb} 1557.7 \mathrm{bn}$, and the averaged amount of reserves in the period between 10 August 2015 and 10 September 2015 amounted to Rb 1068.6bn (by $1.9 \%$ higher than that in the previous period). In the period between 10 August 2015 and 10 September 2015 commercial banks' surplus reserves ${ }^{1}$ averaged $\mathrm{Rb} 389.0$ bn (by $19.3 \%$ lower than that in the previous period), of which banks' deposits on the accounts held with the Russian central bank averaged $\mathrm{Rb} 270.6 \mathrm{bn}$, remaining almost unchanged compared to the previous period, and correspondent accounts, less the averaged amount of reserves, in the period under review were running at an average of $\mathrm{Rb} 118.5 \mathrm{bn}$ (by $23.2 \%$ lower than that in the previous period).

As of 1 September 2015, the amount of loans, deposits and other funds raised by credit institutions from the Bank of Russia reached Rb 6.5 trillion, a decrease by $2.5 \%$ since earlier in August. Banks' debt on repos decreased by $23.3 \%$ to $\mathrm{Rb} 1.2$ trillion, and debts on loans secured by non-marketable assets remained almost the same, Rb 3.0 trillion (Fig. 4). Banks' debt on repos in September increased $13.4 \%$ to $\mathrm{Rb} 1.5$ trillion and debts on other loans decreased to $\mathrm{Rb} 2.7$ trillion due to the tax period and higher demand for ruble-denominated liquidity.

In August 2015, the MIACR (Moscow InterBank Actual Credit Rate) on overnight interbank loans denominated in rubles didn't hit the interest rate band cap and stood within an average range of $10.86 \%$ (11.5\% in July 2015). In September, the interbank aver-age lending rate was $11.1 \%$ (Fig. 5). As a reminder, the average MIACR decreased following the Bank of Russia decision of 31 July to cut the base rate by 0.5 p.p. to $11 \%$ p.a.

Banks' foreign currency debt to the Russian central bank in August 2015 remained almost unchanged and as of the beginning of September amounted to $\$ 33 \mathrm{bn}$. According to the data on 29 September, banks' cur-

1 Commercial banks' surplus reserves held with Russia's Central Bank is the amount of commercial banks' deposits held with the Bank of Russia and correspondent accounts less the averaged amount of required reserves.

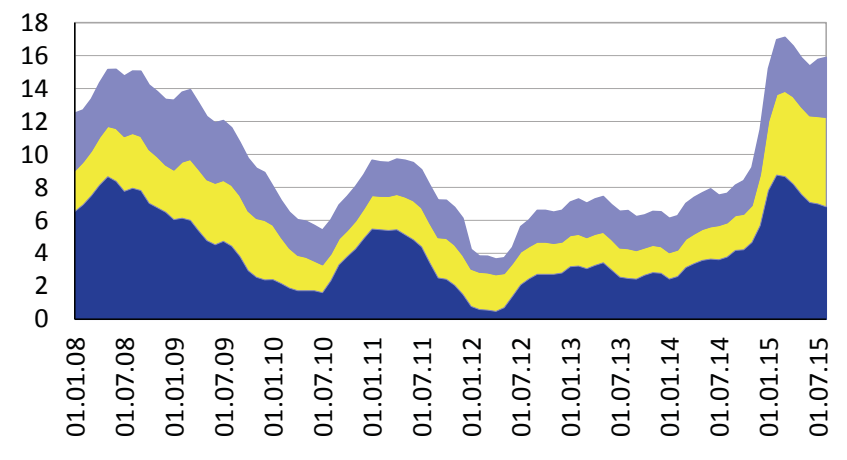

घhood products $\square$ Non-food products $\quad$ Services

Source: Rosstat.

Fig. 2. The contribution of the key components to the CPI on a year-over-year basis in 2008 to 2015

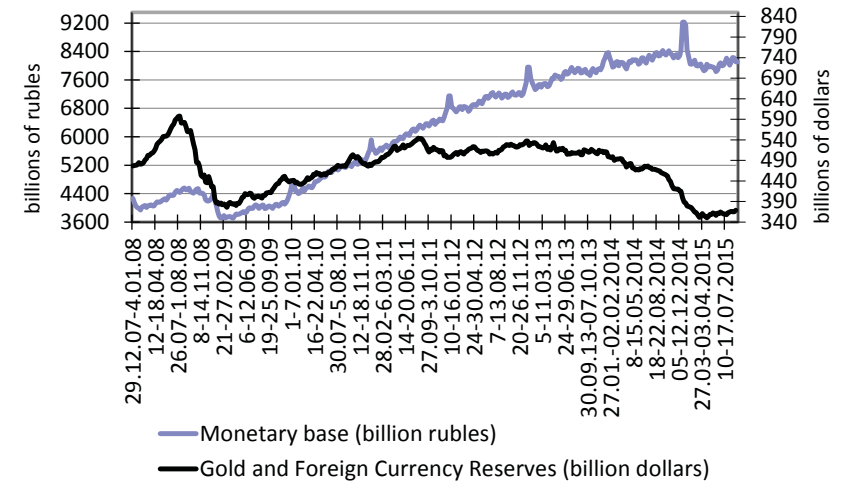

Source: The Central Bank of Russia.

Fig. 3. The dynamics of the monetary base (narrow definition) and the Russian Federation international reserves in 2007 to 2015

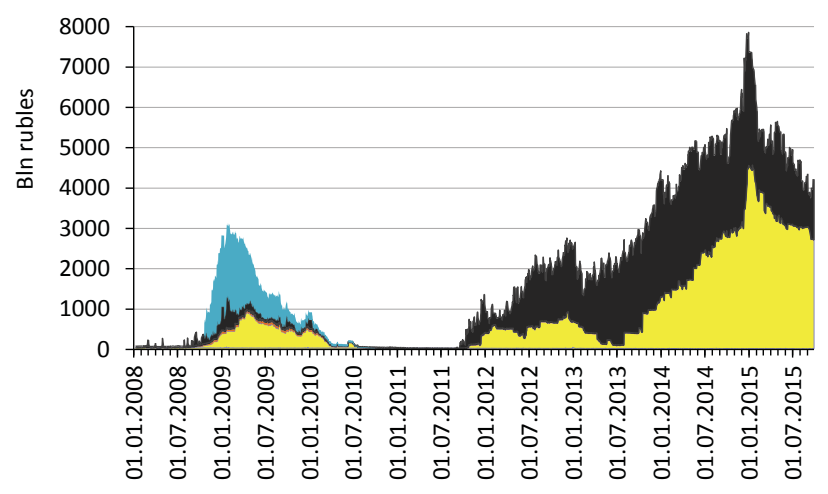

口 Overnight loans' debt $\square$ Other loans' debt $\quad$ Lombard loans' debt

- РEחO Unsecured loans

Source: The Central Bank of Russia.

Fig. 4. Commercial banks' ruble-denominated debt (in key instruments) to the Bank of Russia in 2008 to 2015

rency repo debt to the Russian central bank decreased by $4.9 \%$ to $\$ 31.3 \mathrm{bn}$ including $\$ 26.0 \mathrm{bn}$ on repos for a term of one year and $\$ 5.4 \mathrm{bn}$ for a term of 28 days. Due to upcoming maturities of foreign loans taken out by 
Russian companies and payments on annual currency repo auctions the regulator has stated that it will make decisions where necessary to refinance banks' current foreign currency debt to the Russian central bank and resume using this instrument to be able to provide currency liquidity. It is our opinion, however, that the instrument must not be used until financial sustainability is at risk, and in general the ruble exchange rate must keep floating to allow the economy to adapt more efficiently to changes in the terms of trade.

The Bank of Russia held on 7 August 2015 a credit auction to provide commercial banks with dollardenominated loans secured by pledge of receivables. amount of funds lent for a term of 28 days at an interest rate of $2.44 \%$ p.a. was equal to $\$ 443.0 \mathrm{~m}$. A similar auction was held on 4 September 2015, \$444.0m were lent for a term of 28 days at an interest rate of $2.45 \%$ p.a..

As a reminder, the Russian central bank announced on 29 July 2015 that it had stopped buying foreign currency to increase its international reserves. The decision was made with a view to reducing the demand for foreign currency which increased in the market following another fall of oil prices. As a result, in August 2015 the Bank of Russia performed no currency interventions, whereas in July the regulator purchased foreign currency $\$ 3.8 \mathrm{bn}$. At the same time, in August the Russian central bank increased its internati onal reserves from $\$ 357.6 \mathrm{bn}$ to $\$ 366.3 \mathrm{bn}$ (as of 1 September 2015) mostly due to their currency revalu-ation.

It should be noted that according to the central bank's monetary policy report in September, the international reserves are expected to increase only under an optimistic scenario (the annual average price of Urals oil will gradually increase to $\$ \mathbf{\$ 0 - 8 0}$ per barrel in 2018). It is our opinion that the foregoing actually implies that the Bank of Russia has refused to increase its international reserves until, at least, oil prices see an uptrend. Furthermore, should the situation in the forex market deteriorate further, the Bank of Russia may extend foreign currency provision as part of repos.

According to the central bank's preliminary estimate, net capital outflow from the country in Q2 2015 reached $\$ 20 \mathrm{bn}, 8.3 \%$ less than in the same period of 2014. Net capital export in Q2 2015 through banks and other sectors was running at $\$ 14.1 \mathrm{bn}$ and $\$ 18.4 \mathrm{bn}$, respectively. As a reminder, capital outflow in $\mathrm{H} 22015$ totaled $\mathrm{Rb} 52.5 \mathrm{bn}, 24.4 \%$ less than in the same period of 2014.

The ruble depreciated in real terms in August. The ruble's real effective exchange rate against foreign currencies weakened by $11.4 \%(-2.5 \%$ in July 2015). Overall, the ruble's real effective exchange

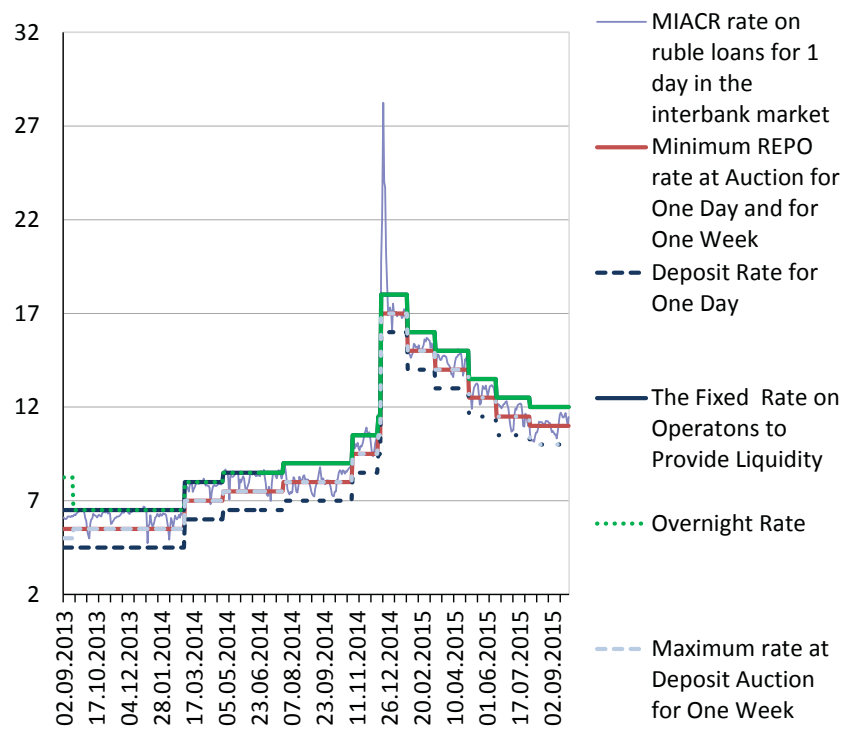

Source: The Central Bank of Russia.

Fig. 5. The Bank of Russia interest rate band and the dynamics of the interbank lending market in 2012 to 2015 (in percent per annum)

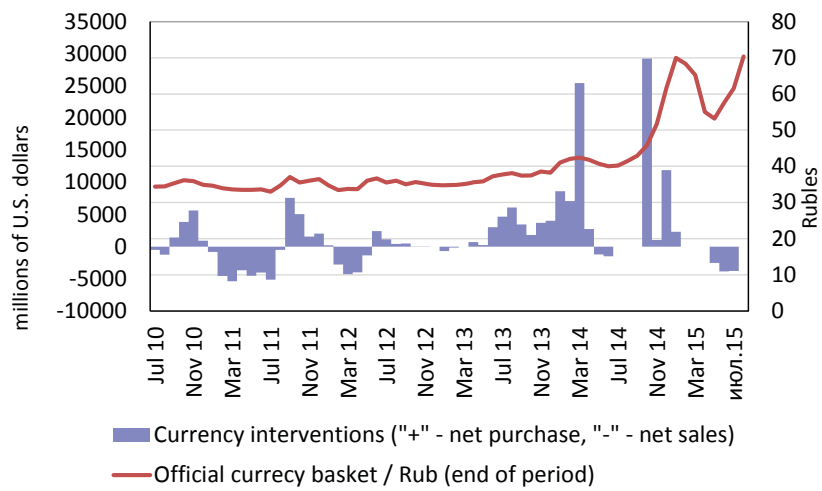

Source: The Central Bank of Russia.

Fig. 6. Bank of Russia's foreign currency interventions and the ruble exchange rate against the currency basket in March 2010 - August 2015

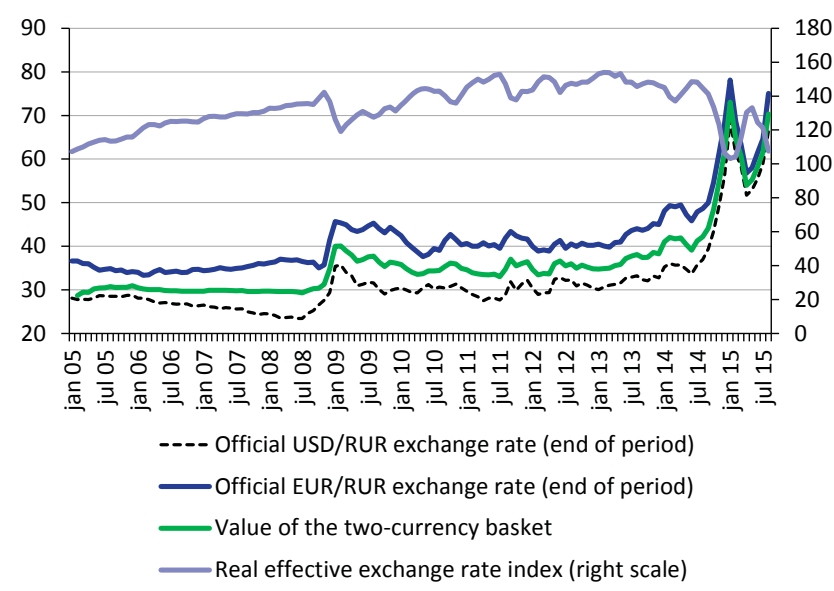

Source: The Central Bank of Russia.

Fig. 7. Ruble exchange rate indicators in January 2005 - August 2015 
rate in January-August 2015 decreased by $18.6 \%$ from January-August 2014 (Fig. 7).

The ruble in August weakened against the US dollar by $10.6 \%$, from 60.3 rubles per US dollar to 66.7 rubles per US dollar, the euro against the ruble gained $13.4 \%$, to 74.8 rubles per euro, and the value of the dual-cur-rency basket increased $11.9 \%$ to 70.4 rubles. As a result, the ruble reached the value seen earlier in the year, outrunning the record values recorded in December 2014 (67.8 rubles per US dollar on 17 December, 70.7 rubles per US dollar on 25 August). It is the oil price fall (by an average of $15.3 \%$ in August 2015) that was the key factor of the ruble depreciati on.

According to our estimates based on the data as of the end of August 2015, the ruble real effective exchange rate stood at a level around the equilibrium value which is determined by fundamental factors (crude oil price, economic growth rates, flight of capitals and government spending). At the same time, due to high inflation in 2015 despite the ruble's devaluation in August, the ruble real effective exchange rate is $1.3 \%$ higher compared to that in December 2014 and corresponds approximately to the level which was seen early in 2005.

The Russian central bank decided on its meeting on 11 September to retain the base rate at $11 \%$ p.a. because of the drastic depreciation of the ruble in August. It is most probable amid growing inflation expectations, risks of devaluation, as well as risks of worsen foreign trade and political situation that no further monetary easing is going be seen in the months to come.

It should be noted that it is set forth in The Guidelines for the State Single Monetary Policy in 2016-2018 that decisions on changes to the central bank base rate will be driven by a situation in the oil market. In particular, while the baseline scenario (the annual average oil price within 2016-2018 will remain near $\$ 50$ per barrel) and the optimistic scenario (the annual average price of Urals oil will gradually increase to \$70-80 per barrel in 2018) provide for monetary easing as inflation gets closer to the mid-term target of $4 \%$, the stress scenario (oil prices will see a drastic fall) plans for implementing a tighter than in the baseline scenario monetary policy. Since the oil price is unlikely to increase substantially in the mid run, a moderately tight monetary policy will ensure that inflation expectations are under control and the 2017 inflation target is fulfilled. 